\title{
Atrial Natriuretic Factor
}

National Cancer Institute

\section{Source}

National Cancer Institute. Atrial Natriuretic Factor. NCI Thesaurus. Code C139911.

Atrial natriuretic factor (28 aa, $\sim 3 \mathrm{kDa}$ ) is encoded by the human NPPA gene. This protein is involved in both cardiac homeostasis and pregnancy. 